\title{
EDUCAÇÃO INFANTIL: HISTÓRIA, FORMAÇÃO E DESAFIOS
}

\author{
FONSECA, André Dioney (Brasil, Pará, Santarém) ${ }^{1 \times}$ \\ COLARES, Anselmo Alencar (Brasil, Pará, Santarém) $)^{1+*}$ \\ COSTA, Sinara Almeida da (Brasil, Pará, Santarém) \\ Universidade Federal do Oeste do Pará \\ ORCID ID: https://orcid.org/0000-0003-0220-5117 \\ ORCID ID: https://orcid.org/0000-0002-1767-5640* \\ ORCID ID: https://orcid.org/0000-0002-2605-4192
}

\section{RESUMO}

Considerando que o exercício analítico histórico é essencial na compreensão das barreiras que travam o desenvolvimento das políticas públicas voltadas à melhoria da Educação Infantil no Brasil, propõe-se, neste artigo de caráter teórico, apresentar alguns elementos históricos sobre as origens distintas das creches e pré-escolas, discutir os papéis assumidos pelos professores de Educação Infantil ao longo dos séculos e, por fim, identificar quais são os desafios a serem enfrentados na formação docente nos dias atuais. Defende-se que a melhoria na qualidade dos serviços de educação oferecidos às crianças pequenas depende do comprometimento com uma formação de qualidade de seus professores, mas também de uma ampla conscientização da sociedade sobre a importância de o Estado brasileiro priorizar a educação, especialmente a infantil, em sua política orçamentária.

\section{PALAVRAS-CHAVE}

Educação Infantil. Docência. Formação.

\section{EARLY CHILDHOOD EDUCATION:}

\section{HISTORY, QUALIFICATION AND CHALLENGES}

\begin{abstract}
Whereas the historically analytical exercise is essential to understand and overcome the obstacles that hinder the development of public policies focussed on the improvement of early childhood education in Brazil, in this theoretical article we intend to present some historical elements about the different origins of nurseries and preschools, and to discuss the roles assumed by the early childhood education teachers throughout the centuries. Finally, we aim to identify what are the challenges to be faced in teacher qualification nowadays. We argue that the improvement in the educational services provided to young children relies on committing to a qualified training of the teachers, along with raising awareness about the importance of the Brazilian government prioritizing education in its fiscal policy, specially children's education.
\end{abstract}

\section{KEYWORDS}

Early childhood education. Teaching. Qualification. 


\title{
EDUCACIÓN INFANTIL: HISTORIA, CAPACITACIÓN Y DESAFÍOS
}

\begin{abstract}
RESUMEN
Considerando que el ejercicio analítico histórico es esencial en la comprensión de las barreras que frenan el desarrollo de las políticas públicas orientadas a la mejora de la Educación Infantil en Brasil, se propone, en este artículo teórico, presentar algunos elementos históricos sobre los orígenes distintos de las guarderías y de las unidad preescolares, discutir los papeles asumidos por los profesores de Educación Infantil a lo largo de los siglos y, por último, identificar cuáles son los desafíos a ser enfrentados en la formación docente en los días actuales. Se defiende que la mejora en la calidad de los servicios de educación ofrecidos a los niños pequeños depende del compromiso con una formación de calidad de sus profesores, pero también de una amplia concientización de la sociedad sobre la importancia de que el Estado brasileño priorice la educación, especialmente la infantil, en su política presupuestaria.
\end{abstract}

\section{PALABRAS CLAVE}

Educación Infantil. Enseñanza. Capacitación.

\section{INTRODUÇÃO}

O resultado do Censo Escolar de 2018 trouxe dados preocupantes sobre a Educação Infantil no Brasil. A sinopse das estatísticas, por exemplo, dá conta de que houve redução no número de pré-escolas, de 106.204 unidades, em 2016, para 105.200, em 2017, e de escolas de Educação Infantil, de 117.191, em 2016, para 116.472, em 2017. No caso das creches, aquilo que poderia ser um elemento animador, já que houve leve aumento no total de unidades, de 65.249, em 2016, para 67.902, em 2017, foi frustrado pelos dados relacionados com a infraestrutura, isso em razão da precariedade das instalações em que funcionam esses espaços de atendimento à primeira infância.

A realidade expressa nesses números, após 30 anos da promulgação da Constituição Cidadã, que tinha como principal objetivo firmar um pacto social e tributário que pudesse garantir o financiamento da educação em todos os níveis, mostra o quanto o Estado brasileiro vem se distanciando dos deveres pactuados na letra constitucional (CAMARA, 2013), cenário que se torna ainda mais crítico se levarmos em conta as medidas compressoras na área macroeconômica, sobretudo aquelas aprovadas após a chegada de Michel Temer ao governo, em 2016, e que se tenta aprofundar na atual administração. O Novo Regime Fiscal (NRF), que, pela Emenda Constitucional n. 95, condiciona o crescimento das despesas primárias aos limites dos índices inflacionários

Educação \& Formação, Fortaleza, v. 4, n. 12, p. 82-103 set./out. 2019

DOI: https://doi.org/10.25053/redufor.v4i12.1270

http://seer.uece.br/redufor 
do ano anterior, é um exemplo exclamativo de ataque ao poder de financiamento do Estado brasileiro, dificultando a correção de distorções históricas, como as expressas no Censo Educacional de 2018. Como a Educação Infantil, pela ausência histórica de investimento, é a etapa educacional com maior carência, certamente não há espaço para um olhar otimista nesse novo modelo fiscal, que privilegia o pagamento de juros, encargos e amortização da assim chamada "dívida pública", em detrimento dos serviços públicos essenciais.

Tudo isso chama a atenção para a necessidade de uma discussão histórica que permita a reflexão sobre os motivos de um setor tão estratégico e sensível como o da Educação Infantil ter sido relegado pelo Estado brasileiro ao longo de décadas e que, ainda hoje, embora já tenha seu lugar reconhecido na Educação Básica, continua dependente de formas de financiamento que estão longe do ideal (MACÊDO; DIAS, 2011).

A vigente Lei de Diretrizes e Bases da Educação Nacional (LDB), Lei n. 9.394/1996, é categórica ao assinalar, em seu artigo 29, a finalidade da Educação Infantil como "[...] o desenvolvimento integral da criança até cinco anos de idade, em seus aspectos físico, psicológico, intelectual e social, complementando a ação da família e da comunidade". Já as Diretrizes Curriculares Nacionais para a Educação Infantil trazem a seguinte compreensão sobre Educação Infantil:

\begin{abstract}
Primeira etapa da educação básica, oferecida em creches e pré-escolas, as quais se caracterizam como espaços institucionais não domésticos que constituem estabelecimentos educacionais públicos ou privados que educam e cuidam de crianças de 0 a 5 anos de idade no período diurno, em jornada integral ou parcial, regulados e supervisionados por órgão competente do sistema de ensino e submetidos a controle social. É dever do Estado garantir a oferta de Educação Infantil pública, gratuita e de qualidade, sem requisito de seleção. (BRASIL, 2010, p. 12).
\end{abstract}

Essa determinação, entretanto, não é suficiente para estabelecer, de forma concreta, a identidade dessa primeira etapa da Educação Básica, tarefa complexa, que envolve a participação de vários sujeitos, entre os quais os professores e as crianças. Tal distinção fica ainda mais acentuada ao serem lembradas as origens distintas das duas etapas que a compõem. Considerando que o exercício analítico histórico é essencial na compreensão e superação das barreiras que travam o desenvolvimento das políticas públicas voltadas à melhoria na Educação Infantil em nosso país, propomo-nos, neste artigo, a apresentar alguns elementos históricos sobre as origens distintas das

Educação \& Formação, Fortaleza, v. 4, n. 12, p. 82-103 set./out. 2019

DOI: https://doi.org/10.25053/redufor.v4i12.1270

http://seer.uece.br/redufor 
creches e pré-escolas, discutir os papéis assumidos pelos professores de Educação Infantil ao longo dos séculos e, por fim, identificar quais são os desafios a serem enfrentados na formação docente.

\section{CRECHES E PRÉ-ESCOLAS: DUAS ORIGENS PARA A ELABORAÇÃO DE UMA REALIDADE}

A Educação Infantil é um daqueles assuntos que têm raízes históricas bem profundas. Lascarides e Blythe (2000) apontam, por exemplo, que, em sociedades da Antiguidade, como Grécia e Roma, a Educação Infantil era um importante aspecto sociopolítico, pois, como a família era a unidade primária na organização social e econômica desses povos, a vida política era uma extensão da família para o domínio público, daí o cuidado do ensino nos primeiros anos de vida da criança, que, por meio de tutores, aprendia os rudimentos da vida social, da língua, da disciplina psicomotora, entre outros.

No período medieval, esclarecem os autores, a situação de escassez de recursos que atingia a maior parte da população limitava a primeira educação às crianças de classe alta, que recebiam ensinamentos em casa pelo pai ou professor particular a partir dos 5 ou 6 anos de idade (LASCARIDES; BLYTHE, 2000). Espaços coletivos, como as creches, já na Idade Moderna, tiveram seu início ligado aos asilos infantis, cujo principal objetivo era mediar uma situação de enorme precariedade por meio do atendimento às necessidades imediatas dos desamparados, como alimentação, vestuário e abrigo. Segundo Kuhlmann Junior (1998), as creches para crianças de 0 a 3 anos de idade foram a alternativa para que as mães não abandonassem mais suas crianças nas Casas dos Expostos, atitude comum nos séculos XVII e XVIII, sobretudo em virtude da situação de extrema pobreza e miséria de grande parcela da população.

Ainda segundo Kuhlmann Junior (1998), uma das características primordiais da educação assistencialista era a baixa qualidade do atendimento como seu objetivo, uma educação mais moral do que intelectual para que as crianças não pensassem muito sobre sua realidade e se sentissem resignadas em sua condição social ${ }^{1}$. Outra

${ }^{1}$ É importante destacar que Kuhlmann Junior (1998) reconhece algumas especificidades, pois nos atendimentos ditos assistencialistas havia propostas educativas.

Educação \& Formação, Fortaleza, v. 4, n. 12, p. 82-103 set./out. 2019

DOI: https://doi.org/10.25053/redufor.v4i12.1270

http://seer.uece.br/redufor 
peculiaridade era isolar a criança de possíveis meios de contaminação por doenças transmissíveis, sendo a rua o principal deles. Essa ação era considerada uma virtude pedagógica e, dessa forma, o atendimento educacional à criança passou a ser visto como um favor aos pobres e a frequente baixa qualidade a ser aceita como algo natural.

As pré-escolas, por sua vez, tiveram origem distinta. Foi na Alemanha de 1848, com os kindergartens (jardins de infância), de Friedrich Fröebel (1782-1852), que ocorreram as primeiras experiências com esse tipo de espaço específico. Nos kindergartens, as crianças - tidas como pequenas sementes que, adubadas e expostas a condições favoráveis em seu meio ambiente, desabrochariam em um clima de amor e simpatia - estariam livres para aprender sobre si mesmas e sobre o mundo. Essas instituições concediam maior atenção à área cognitiva e não priorizavam apenas o cuidado, mas o desenvolvimento infantil como um todo. Inicialmente esse atendimento também foi voltado às classes populares, mas rapidamente foi apropriado pela burguesia, que percebeu as vantagens de uma boa educação para suas crianças.

De acordo com Kuhlmann Junior (1998), no início do século XX, as instituições pré-escolares foram difundidas internacionalmente como parte de um conjunto de medidas que conformavam uma nova concepção assistencial, a assistência científica, abarcando aspectos como a alimentação e a habitação dos trabalhadores e dos pobres, sendo sua grande marca a postulação, que era entendida como proposta moderna e científica. A difusão das teorias da privação cultural, na década de 1970, embasou a origem da chamada educação compensatória, que tinha por função, como a própria nomenclatura indica, compensar as supostas carências que as crianças pobres teriam. Essa teoria educacional passou a ser muito criticada pelos educadores, haja vista que a supervalorização de medidas assistenciais teria como consequência a deterioração do salário dos professores e a diminuição das verbas destinadas à educação. A culpa da ausência de qualidade no ensino parecia recair sobre o que se acreditava ser um "excesso" de atenção dispensada à nutrição em detrimento dos aspectos educacionais. Foi nesse contexto que educação passou a ser considerada o oposto de assistência.

Em concordância ainda com Kuhlmann Junior (2005), o distanciamento entre assistência e educação opõe a função de guarda à função educativa, como se ambas fossem inconciliáveis. É importante salientar, porém, que as creches não tinham caráter exclusivamente assistencial, mas eram também, no sentido mais amplo, educativas. Da 
mesma forma, os jardins de infância não eram exclusivamente pedagógicos. Segundo esse autor, as áreas educacional e assistencial faziam-se e fazem-se presentes nos dois casos, de modo que essas trajetórias paralelas encontraram muitos canais de comunicação durante toda a sua história. O conceito de creche, contudo, ainda hoje traz consigo ideias e sentimentos que remetem a instituições ligadas apenas a cuidados corporais, como higiene e alimentação, que atendem à classe subalterna em período integral e que têm função assistencial. Já quando se fala em pré-escola, são despertados pensamentos e emoções relativos a instituições com objetivos educacionais destinadas às classes privilegiadas, de meio período, com a função de preparar a criança para o Ensino Fundamental.

Segundo Zabalza (1998), a escola infantil, além dos desafios comuns a todo o sistema educativo, apresenta outros, específicos de sua área, como reforçar a própria identidade e a autonomia formativa, reforçar os laços de conexão entre ela e o meio ambiente e entre ela e o Ensino Fundamental, que deve ser visto como etapa de continuidade curricular. No Brasil, o aumento do número de pesquisas sobre a criança e sua educação (ROCHA, 1999), bem como a criação e a atuação de uma Coordenadoria de Educação Infantil, ligada ao Ministério da Educação (MEC), e a incorporação da Educação Infantil ao sistema de ensino são exemplos atuais de como a sociedade está procurando superar esses desafios. Tais medidas também corroboram o reconhecimento e a formulação de uma nova identidade dessa etapa de prática social que é a Educação Infantil.

É importante salientar que, de acordo com Silva e Rossetti-Ferreira (2000), esses avanços são expressões de outros tantos que vinham ocorrendo no campo da produção de conhecimento sobre a criança pequena. Um marco importante dessa luta está nas discussões que permearam a sociedade no contexto da Constituinte, década de 1980, quando diversas forças sociais pressionaram seus representantes no sentido de reconhecer a Educação Infantil como direito constitucional. Posteriormente, segundo Oliveira (1994), os encontros da Associação Nacional de Pós-Graduação e Pesquisa em Educação (Anped), desde 1995, fundamentaram as propostas apresentadas e aprovadas na Constituição Federal. Daí a importância crucial da participação da sociedade civil na consolidação da identidade própria da educação da criança pequena, que se torna, a cada dia, mais clara e concreta. 


\section{OS PAPÉIS ASSUMIDOS PELAS PROFESSORAS DE EDUCAÇÃO INFANTIL AO LONGO DOS SÉCULOS}

Conforme visto na seção anterior, de modo geral, as instituições de Educação Infantil, ao longo de sua história, passaram por inúmeras transformações, e a educação da criança pequena cumpriu e ainda cumpre várias funções no decorrer dos séculos, como guarda, proteção, alimentação e compensação de supostas carências que as crianças pobres teriam. Conforme Lascarides e Blythe (2000, p. 24), nas sociedades ocidentais e patriarcais as evidências históricas sobre a infância sugerem que a responsabilidade primária pelas crianças (do nascimento aos 7 anos de idade) esteve exclusivamente nas mãos das mulheres. Com a institucionalização de espaços específicos de Educação Infantil, a partir do século XVIII, na Europa, a figura da professora como profissional primaz desse novo lócus de ensino consolidou-se ao longo dos séculos. A compreensão que se tem da instituição de Educação Infantil permite vislumbrar qual é ou deveria ser o papel da professora, papel esse influenciado pelo que essa profissional pensa acerca da creche, da pré-escola e da população que é atendida no interior dessas instituições.

Várias foram as denominações, bem como as funções, referentes à professora da primeira etapa da Educação Básica no decorrer dos séculos: pajem, monitora, jardineira, mestra, tia, entre outras. Tais designações estão intrinsecamente ligadas aos objetivos da Educação Infantil em determinados momentos históricos da sociedade. Em sua origem, as creches foram consideradas uma modalidade de caridade e, dadas as próprias características inerentes a esse tipo de entidade, as atividades nelas exercidas guardavam também um caráter de trabalho leigo, voluntário, mais dependente do idealismo e da boa vontade das pessoas envolvidas do que de uma formação profissional específica (CAMPOS et al., 1991). Essa visão dificultou que as pajens, profissionais que atuavam diretamente com as crianças, reivindicassem possíveis melhorias salariais e de condições de trabalho, já que essa atitude teria um caráter negativo, na medida em que se contrapunha à imagem de caridade e de favor associada ao tipo de atendimento destinado à população mais pobre.

A diversificação de propostas de atendimento, que tinham como premissa a redução de custos, introduziu uma nova categoria de pessoal que atuava diretamente 
com as crianças: a monitora, sem formação especializada, que atendia a grupos numerosos a partir de uma orientação, mais ou menos próxima, de professoras ou técnicos. Segundo Campos et al. (1991), as peculiaridades do atendimento às crianças pequenas, principalmente em creches, têm contribuído negativamente para que as pessoas responsáveis pelas crianças nessas instituições construam uma identidade profissional. Entre essas particularidades, estão: "1. a de desempenhar, integrada à sua ação educativa, a função de garantir, durante parte do dia, a sobrevivência do educando; 2. a de atuar junto à população mais jovem de educandos" (CAMPOS et al., 1991, p. 48). Assim, o fato de muitas atividades desenvolvidas na creche implicarem uma interação mais "corpo a corpo" concorre para que não sejam percebidas como educativas (estas seriam reservadas a atividades mais próximas ao modelo escolar) e delegadas à esfera do doméstico, o que induz a uma desvalorização profissional.

Campos et al. (1991) chamam a atenção ainda para o fato de que tais especificidades do trabalho com crianças pequenas interferem inclusive na hierarquia de cargos e funções no interior das instituições educativas. Segundo a autora, são pelo menos três tipos de fatores envolvidos nessa relação:

- atividade direta com o educando (quanto mais diretamente ligada ao educando menor o prestígio do profissional); - idade do educando (quanto menor o educando menor o prestígio do profissional); - proximidade do corpo (quanto mais imediatamente ligado à sobrevivência - e, portanto, ao corpo - do educando, menor o prestígio do profissional). (CAMPOS et al., 1991, p. 49).

Essas reflexões podem facilitar a compreensão de algumas situações de trabalho vivenciadas por profissionais dessa etapa educacional e que ainda hoje se fazem presentes tanto no interior de uma mesma instituição quanto no confronto com outras. Um exemplo é a diferença salarial entre as professoras de Educação Infantil e aquelas das demais etapas da Educação Básica, ou ainda entre as docentes que atuam em creches e as que trabalham em pré-escolas. Na origem dos jardins de infância, na Alemanha de 1848, surgiu ainda outra personalidade responsável pela criança: a jardineira. Essa personagem deveria concentrar-se, em seu trabalho, nos interesses e nas necessidades das crianças, que deveriam ser tratadas por ela com todo amor e carinho, mas sem interferir em seu crescimento. As jardineiras tinham guias de trabalho, manuais, também destinados às mães, que mesclavam germens de uma psicologia do 
desenvolvimento com a religião. Dessa forma, Fröebel começou a definir essa mulher não como profissional, mas como uma "meia mãe", que conhecia os interesses e as necessidades das crianças, mas que tinha essencialmente um "coração de mãe" a nortear sua conduta (ARCE, 2001).

Para Montessori, discípula de Fröebel no início do século XX, a psicologia do desenvolvimento forneceria a cientificidade necessária para que essa mulher, de simples jardineira, fosse elevada à categoria de mestra; entretanto, à mestra, ou professorinha, como era por vezes chamada no cotidiano das salas de Educação Infantil, caberia apenas o papel de coadjuvante no ensino-aprendizagem, sendo sua principal função organizar as condições ambientais para que a criança pudesse agir de forma autônoma.

$\mathrm{Na}$ perspectiva da educação compensatória no Brasil do fim século XX, as carências das crianças pobres deveriam ser supridas por meio de sua preparação para a alfabetização; a atitude exigida daquela que seria responsável por sua educação nas pré-escolas também mudou. A partir daí, suas ações ganharam um caráter mais formal de "ensino", como transmissoras de conhecimentos. Essa figura assemelha-se à figura da "tia", que se propaga até os dias de hoje nas instituições de Educação Infantil, demonstrando uma caracterização pouco definida da profissional que atua com crianças pequenas. Segundo Arce (2001, p. 174):

[...] essa mulher/mãe não chega a ser professora devido à proximidade extrema que seu trabalho possui com o doméstico e o privado [...] e por outro lado não chega a ser mãe, pois, biologicamente, não foi ela a responsável por todas aquelas crianças que ficam sob seus cuidados.

Kramer (2005) chama a atenção para o fato de o significado dessas denominações a que são submetidas as professoras poder influenciar a visão que elas têm de si mesmas, de sua autoridade e poder. Para tanto, a autora remete a Bakhtin no que se refere aos processos de constituição da subjetividade. Conforme o estudioso, quando a expressão é materializada mediante a linguagem, ela exerce um efeito reversivo sobre a atividade mental. Assim, o mundo exterior vai sendo adaptado às possibilidades da expressão, suas tendências e orientações, processo que vai constituindo o que ele denominou "ideologia do cotidiano", que, embora não seja fixa ou ordenada em um sistema, acompanha os atos dos sujeitos e seus estados de consciência (BAKHTIN, 2010). 
É interessante atentar ainda para a pequena (praticamente inexistente!) participação masculina entre as professoras da Educação Infantil ao longo da história até os dias de hoje. Segundo Cerisara (2002), a busca da identidade profissional das professoras de crianças pequenas exige que seja levado em consideração o gênero a que ela pertence, já que a categoria gênero é uma dimensão decisiva na organização da igualdade e da desigualdade na sociedade. Não é demais lembrar, seguindo as considerações da historiadora Scott (1990, p. 14), que "[...] o gênero é um elemento constitutivo de relações sociais baseado nas diferenças percebidas entre os sexos, e 0 gênero é uma forma primeira de significar as relações de poder".

De acordo com Campos et al. (1991), esse afastamento do homem de profissões ligadas à Educação Infantil pode ser compreendido tanto pelo atributo de trabalho "sujo" (principalmente em relação às creches) quanto pelos menores salários oferecidos para esse trabalho. Além disso, a autora acrescenta outro complicador a essa lista: a sensualidade que impregna a interação adulto-criança pequena. Apesar de interdito, "[...] suspeitar [d]a presença do desejo nessa relação é mais facilmente admissível na interação mulher-criança que na homem-criança" (CAMPOS et al., 1991, p. 54). Assim, quando homens dedicam-se ao trabalho educativo com crianças pequenas passam a ser "suspeitos" em relação tanto à sua moralidade quanto à sua masculinidade. Esse fato é preocupante, haja vista a importância de as crianças poderem contar também com 0 referencial masculino nas instituições de Educação Infantil, o que é indispensável a seu processo de socialização e de desenvolvimento, como destaca Cerisara (1996, p. 166):

\begin{abstract}
O movimento que busca a integração e a complementaridade entre feminino e masculino supõe que se abra espaço para que o homem possa lidar com o afeto, o sentimento, a maternagem, assim como para práticas profissionais com feições masculinas dentro das instituições de Educação Infantil, com vistas a colaborar para a ruptura das discriminações de gênero nas ocupações ligadas ao cuidado e à educação das crianças de 0 a 6 anos e a contribuir para o processo de socialização de meninos e meninas.
\end{abstract}

Ainda em relação a esse tema, é importante atentar para os modelos educativos propostos pelo Banco Mundial, que preveem a recriação de programas que sustentem a subordinação de gênero, como as creches domiciliares. Na concepção de Rosemberg (2002, p. 58), esses programas: 
[...] consideram que as mulheres são destinadas a permanecer em casa cuidando de seus filhos ou dos filhos de outras mulheres, sem receber formação e titulação profissional; que mulheres com escolaridade incompleta merecem 'cursos para mães', com verbas da Educação Infantil[,] e não uma formação completa como cidadãs no contexto da educação de jovens e adultos; que homens são seres inadequados para educar e cuidar de crianças.

Os inúmeros avanços legais e científicos, contudo, que foram alcançados em relação não só à mulher, mas também às crianças, principalmente por meio da promulgação da Constituição de 1988 e da divulgação dos estudos sociointeracionistas de desenvolvimento e aprendizagem humana, implicam uma reestruturação das relações sociais como um todo e a criação de equipamentos sociais. Nessa nova visão da criança como sujeito de direitos, protagonista histórico e cidadão em desenvolvimento, a figura do professor não é mais aquela que molda comportamentos ou repassa conhecimentos aos alunos, mas a de interlocutor que aponta caminhos, organiza ambientes e materiais e troca informações com o educando, em um processo recíproco de crescimento.

Consoante Campos (1994), as duas modalidades de atendimento voltadas para a criança pequena no Brasil, geralmente denominadas "assistencial" e "educacional", sendo a primeira destinada à camada popular, e a segunda, à classe média, estão longe de responder às concepções mais atuais de desenvolvimento infantil. Isso porque essas novas concepções fundamentam suas propostas curriculares em critérios de qualidade definidos por grupos de pesquisadores europeus, especialmente os italianos, que, por sua vez, trazem nessas propostas um caráter integrado, sem privilegiar um aspecto em detrimento do outro, mas procurando dar conta de todos, na medida das necessidades e dos interesses das crianças e também de acordo com os padrões e valores culturais e da sociedade na qual elas estão inseridas. Assim:

[...] a perspectiva coerente com a moderna noção de cuidado tem sido usada para incluir todas as atividades ligadas à proteção de qualquer criança: alimentar, lavar, trocar, curar, proteger, consolar, enfim, 'cuidar', todas fazendo parte integrante do que chamamos de 'educar'. (CAMPOS, 1994, p. 35).

Kramer (2005), entretanto, chama a atenção para o fato de que o binômio cuidar-educar algumas vezes sugere a ideia de duas dimensões independentes: uma relativa ao corpo, sem levar em consideração o fato de que a atividade de cuidar não se restringe à higiene, engloba também a saúde como um todo, os afetos e os valores

Educação \& Formação, Fortaleza, v. 4, n. 12, p. 82-103 set./out. 2019

DOI: https://doi.org/10.25053/redufor.v4i12.1270

http://seer.uece.br/redufor 
morais; e a outra, aos processos cognitivos. Para a autora, "[...] a pedagogia, voltada para o ensino e o trabalho com as ideias, não sabe como lidar com a materialidade do corpo" (KRAMER, 2005, p. 65). Além disso, não se pode esquecer que o cuidar está historicamente vinculado à assistência e ao corpo, tarefa delegada a pessoas desqualificadas profissionalmente, logo:

[...] em espaços de formação de profissionais que atuam junto à criança pequena, é frequente a polêmica em torno das duas atribuições, em especial quando se trata de professoras das redes públicas, que, em inúmeros casos, não assumem para si a função de cuidar por entendê-la como relativa a atividades relacionadas ao corporal e ao doméstico, como dar comida, dar banho, cuidar do espaço em que se trabalha/estuda. (KRAMER, 2005, p. 68-69).

Dessa forma, a separação entre os atos de educar e cuidar também inclui uma conotação hierárquica estabelecida entre professoras e auxiliares, sendo as primeiras responsáveis pela educação da criança, e as últimas, pelos cuidados, em termos bem restritos. De acordo com Cerisara (2002), tal hierarquização, que é oficial entre as duas profissionais, é evidenciada mediante indicadores concretos, como carga horária semanal de trabalho, salário e formação, fato que influencia a diferenciação de funções no interior das instituições. Acredita-se, contudo, em uma visão integrada da Educação Infantil, ou seja, a coexistência desses dois tipos de profissionais, cada um responsável por uma função definida. Oliveira-Formosinho e Formosinho (2001) percebem a interligação entre educação e cuidado como um diferencial do trabalho das professoras da Educação Infantil, o que inviabiliza a separação de funções. Segundo as autoras, esse acúmulo de papéis alarga naturalmente sua função em relação à dos demais profissionais da educação.

Assim, apesar da similaridade entre os papéis das professoras de Educação Infantil e os dos outros professores, existem muitos aspectos particulares ao trabalho das primeiras. Esses aspectos configuram uma profissionalidade específica do trabalho das educadoras de infância. Dessa forma, Oliveira-Formosinho e Formosinho (2001) apresentam um quadro organizado em torno de três dimensões que expressam a singularidade da profissionalidade das educadoras dessa primeira etapa da Educação Básica, que são: 1) características da criança pequena; 2) características dos contextos de trabalho; e 3) características do processo e das tarefas desempenhadas pelas 
educadoras. No tocante à criança pequena, as estudiosas apontam três características específicas decorrentes de seu estádio de desenvolvimento, de seus processos de crescimento e de sua vulnerabilidade. Segundo as autoras, "[...] a criança é um todo integrado com uma dinâmica intensa" (OLIVEIRA-FORMOSINHO; FORMOSINHO, 2001, p. 82). Essa "globalidade" da criança requer das professoras um alargamento de responsabilidade por seu funcionamento, além de proporcionar uma indefinição de fronteiras quanto à sua atuação.

Além dessa característica, a criança pequena apresenta certa dependência do adulto nas rotinas de cuidado (higiene, limpeza, saúde), fato que chama a atenção para sua vulnerabilidade (física, emocional, social) e que tem relação com a necessidade de atenção privilegiada aos aspectos socioemocionais imprescindíveis ao progresso nos diferentes âmbitos do desenvolvimento. No que concerne às características dos contextos de trabalho, Oliveira-Formosinho e Formosinho (2001) apresentam uma variedade de contextos em que se prestam os serviços educacionais, entre os quais estão os contextos pedagógicos (que têm uma intencionalidade educativa assumida) e os contextos de custódias (em que prevalece uma missão centrada na guarda segura e nos cuidados às crianças enquanto seus pais trabalham). Essa diversidade de contextos influencia as condições de trabalho das professoras pertinentes à autonomia profissional, aos processos de trabalho e ao estilo de interação com as crianças.

O âmbito alargado de relações e interações - com crianças, auxiliares, familiares, psicólogos, estagiárias, etc. -, que se requer das educadoras de infância, em vários níveis, também é responsável pela maior abrangência de seu papel e constitui-se em mais uma singularidade de sua profissão. Nas palavras de Oliveira-Formosinho e Formosinho (2001, p. 89), “[...] podemos assim dizer que a profissionalidade da educadora da infância se situa no mundo da interação e que aí desenvolve papéis, funções, atividades, interfaces". Além disso, a especificidade da educação da infância revela-se ainda no fato de ser mais centrada no educando do que no processo educativo ou no educador.

Ainda segundo as autoras, uma vez assegurados os critérios básicos de qualidade, como razão adulto/criança e tamanho do grupo, os fatores mais importantes que contribuem para uma melhor qualidade do trabalho das professoras são: a formação para a individualização do ensino-aprendizagem, a ênfase na atividade autoiniciada pela 
criança, o suporte pelo professor ao desenvolvimento da criança, um clima social positivo e o envolvimento dos pais. Assim, características pessoais e profissionais das educadoras, como a sensibilidade e a aptidão para motivar a criança, definem sua capacidade de interação no ensino-aprendizagem e constituem fator crítico na qualidade do desenvolvimento e da aprendizagem da criança.

Nesse sentido, a Escala de Observação do Empenhamento do Adulto (BERTRAM apud OLIVEIRA-FORMOSINHO; FORMOSINHO, 2001), instrumento metodológico utilizado em vários projetos de pesquisa no Brasil e no exterior que permite focar a visão do observador nas características da intervenção do adulto nas crianças, selecionou como foco três âmbitos de ação da educadora: 1) a sensibilidade do adulto para com a criança; 2) o grau de autonomia que o adulto confere à criança; e 3) o grau de estimulação que o adulto oferece à criança. Sob a óptica de Oliveira-Formosinho e Formosinho (2001), essas três dimensões do trabalho da professora de Educação Infantil propostas pela Escala permitem "adentrar águas profundas" no tocante ao respeito pela criança, bem como à crença em sua competência e, portanto, em sua estimulação, mediante propostas de trabalho que partam de suas necessidades e interesses.

Nessa mesma direção, o papel do professor, em Reggio Emilia (apud EDWARDS, 1999, p. 161), centra-se:

[...] na provocação de oportunidades de descobertas, através de uma espécie de facilitação alerta e inspiradora e de estimulação do diálogo, de ação conjunta e da coconstrução do conhecimento pela criança. Uma vez que a descoberta intelectual é supostamente um processo essencialmente social, o professor auxilia mesmo quando as crianças menores aprendem a ouvir os outros, a levar em consideração seus objetivos e ideias e a se comunicar com sucesso.

Assim, na proposta pedagógica de Reggio, o professor é um verdadeiro "parceiro" das crianças, apoiando-as e oferecendo-Ihes auxílio, recursos e estratégias para que possam prosseguir quando encontrarem dificuldades. É importante, porém, destacar que as representações de professor de Educação Infantil que embasam a filosofia de Reggio Emilia passam por outras, de infância e criança, que, por sua vez, podem ser reinventadas pela sociedade. Dito de outra forma, cada sociedade cria a própria representação do que são as crianças, o que se reflete na escola que lhes é 
proposta. Assim, uma representação forte de criança também é uma representação intensa de professor e de escola.

No caso de Reggio, desde o término da Segunda Guerra Mundial, Malaguzzi dedicou sua vida ao estabelecimento de uma comunidade didática, composta por professores de várias linhas e especialidades, que trabalhou junto por décadas, com pais, membros da sociedade e milhares de crianças, para formar um sistema que hoje funciona. Apesar da grande exigência para que os professores cumpram os ideais sociais, o que demanda muito esforço e dedicação de sua parte, esses profissionais consideram seu trabalho gratificante e envolvente, bem como vital para o progresso da sociedade e o bem-estar humano (GARDNER, 1999).

\section{UMA NOVA FORMAÇÃO PARA UM NOVO PROFESSOR}

Diante de tantas expectativas em relação a esse novo profissional, que está em plena vigência de constituição de sua identidade, a formação específica para o exercício de sua função apresenta-se cada vez mais necessária. Oliveira (2004) argumenta que a formação desse novo educador deve incluir o conhecimento técnico e o desenvolvimento de habilidades para realizar atividades variadas, particularmente expressivas, e para interagir com crianças pequenas. O documento Subsídios para credenciamento e funcionamento de instituições de Educação Infantil (BRASIL, 1998, p. 18) defende que "[...] as crianças precisam de educadores qualificados, articulados, capazes de explicitar a importância, o como e o porquê de sua prática [...]”. Kuhlmann Júnior (1998, p. 65), ao refletir sobre a formulação de propostas pedagógicas que tomem como ponto de partida a criança, alerta: "[...] não é a criança que precisaria dominar conteúdos disciplinares, mas as pessoas que as educam". Nesse sentido, a LDB/1996, em seu artigo 62, traz como exigência a formação mínima em nível médio na modalidade normal para a atuação do professor em turmas de Educação Infantil, o que significa um progresso, se for levado em consideração o número de professoras sem uma formação mínima trabalhando com crianças de até 6 anos ao longo da história.

Até o momento atual, entretanto, uma titulação de nível médio ou superior não garante a preparação adequada para o trabalho com crianças pequenas (CRUZ, 1996). Um aluno do curso de Pedagogia, por exemplo, pode obter o diploma sem ter participado

Educação \& Formação, Fortaleza, v. 4, n. 12, p. 82-103 set./out. 2019 
de uma única disciplina específica da área de Educação Infantil, já que, em grande parte dos cursos, essas disciplinas são optativas. Atento a esse fato, o Conselho de Educação do Ceará, na elaboração da Resolução n. 361/2000, incluiu a exigência de:

[...] haver a inclusão nos programas dos cursos em nível médio e superior (licenciatura, sequenciais ou de pós-graduação) de conteúdos que abordem as seguintes temáticas: desenvolvimento da criança; histórico, concepções e funções da Educação Infantil; estratégias de organização do espaço e dos materiais, no âmbito da Educação Infantil; concepção e estrutura curricular específicas para a Educação Infantil, nelas incluídas as didáticas especiais.

Outro aspecto alvo de atenções, quando se fala na redefinição do currículo dos cursos de Pedagogia, diz respeito à necessidade de ampliar a experiência docente dos alunos em instituições de Educação Infantil. Acredita-se que o contato com crianças desde o início do curso facilitará a compreensão de seu papel nas relações de cuidado e educação das crianças, trazendo discussões enriquecedoras para sua formação e evitando uma possível frustração profissional. Observa-se, pois, que há uma grande diferença entre ter titulação para trabalhar com crianças pequenas e ter formação adequada para esse fim. $O$ primeiro caso diz respeito a um título mediante o qual 0 estudante obtém "autorização", por meio de um diploma, para atuar na Educação Infantil, enquanto o segundo refere-se a todo um processo pelo qual o aluno tem estreito contato com diversos assuntos específicos para trabalhar com essa faixa etária, tendo a oportunidade de refletir sobre inúmeras situações e realidades da área, em que o diploma representa o ápice dessa jornada.

As lutas que vêm sendo travadas em prol de uma formação adequada e de qualidade para as professoras da Educação Infantil não podem esquecer que as condições de trabalho e a valorização profissional, entre outros fatores, também implicam o serviço prestado pelas docentes e precisam ser levadas em consideração pelas políticas públicas. Por outro lado, é preciso ter atenção redobrada para que, na busca de uma melhor formação para as professoras da infância, evitem-se erros antigos, a fim de que se possam vislumbrar maiores chances de sucesso nessa empreitada.

Segundo Cruz (1996), os cursos de formação para professores de Educação Infantil não podem perder de vista dois grandes conjuntos de informações que precisam ser trabalhados: 1) aquele referente à criança e sua família - o desenvolvimento infantil 
em suas múltiplas dimensões; a história, as condições socioeconômicas, os costumes, os valores, as brincadeiras, entre outras, das famílias; 2) e outro, com informações relacionadas com a creche/pré-escola e o trabalho que se deve desenvolver junto às crianças e suas famílias - pequeno histórico e situação atual do atendimento à criança no Brasil; tópicos de linguagem, matemática, ciências, artes e atividades físicas; informações sobre o delineamento da programação, planejamento de rotinas e atividades, organização dos espaços e dos materiais, elaboração de avaliações, etc.; dados sobre as necessidades e os problemas nutricionais da infância, organização de cardápios e sobre a saúde da criança pequena; ética, legislação sobre a criança e o funcionamento das creches e pré-escolas.

Além dos conhecimentos abordados há pouco, a autora enfatiza a necessidade de os cursos de formação desenvolverem as habilidades e competências das professoras, entre as quais a observação (não apenas a da criança, mas a de seu próprio trabalho) e a descentração do próprio ponto de vista, para que possa compreender melhor o pensamento das crianças, a fim de, então, problematizá-lo e instigá-lo.

Após extensa revisão bibliográfica sobre a especificidade da formação do professor de Educação Infantil, Machado (1998) propõe quatro eixos básicos a serem contemplados em propostas de formação para a área: 1) crescimento e desenvolvimento de crianças pequenas - abordando os aspectos básicos de saúde e do desenvolvimento infantil, o período de adaptação, o brinquedo como mediador do desenvolvimento infantil, etc.; 2) profissionais da Educação Infantil e cotidiano - abrangendo a formulação da proposta pedagógica, a organização dos espaços, os materiais disponíveis e as rotinas instituídas, entre outros; 3) identidade profissional - compreendendo preconceitos e estereótipos, ética profissional, implicações do trabalho junto às crianças e suas famílias, possibilidades de formação profissional, etc.; e 4) sistemas educacionais - histórico da Educação Infantil nos sistemas educacionais, legislação, entre outros temas.

Para Oliveira (2003, p. 8, grifos nossos):

[...] como na relação com a criança, o professor repete suas próprias experiências infantis, em sua formação profissional ele precisa reconhecer suas emoções, trabalhar certos sentimentos que lhe desperta a atuação profissional, analisar continuamente suas próprias frustrações e sua agressividade para poder estabelecer uma relação segura com a criança, coconstruir com ela conhecimentos em clima carinhoso e ter uma compreensão mais autônoma do próprio trabalho.

Educação \& Formação, Fortaleza, v. 4, n. 12, p. 82-103 set./out. 2019 
Segundo Porto e Cruz (2004), é essencial que os cursos de formação para professoras de Educação Infantil possibilitem o contato com a brincadeira, haja vista a importância da relação entre a brincadeira e o desenvolvimento infantil. Na visão das autoras, na medida em que as professoras compreendem que a "[...] linguagem do brinquedo pode transformar a vida na/da escola" (PORTO; CRUZ, 2004, p. 220), poderão mudar radicalmente suas práticas educativas. Para que essa conscientização ocorra, porém, e a professora aproprie-se do "conhecimento/sentimento" da importância da brincadeira para as crianças, não é suficiente que o tema seja abordado apenas teoricamente:

\begin{abstract}
É essencial que isso seja feito de forma vivencial para que os professores possam dá-se [sic] conta, por intermédio de suas mãos, dos seus olhos, dos seus ouvidos, do seu corpo, dos seus valores morais e educativos, que o brinquedo é importante para que a criança possa desenvolver-se, tendo um rico contributo não só no aspecto psicológico, como sociocultural e, ainda, no aspecto pedagógico. Por isso é necessário que, além de conhecer o significado do brinquedo, o professor brinque. (PORTO; CRUZ, 2004, p. 221-222).
\end{abstract}

Diante de tudo o que foi posto até aqui, fica evidente que, se existe a pretensão de melhoria na qualidade dos serviços oferecidos às crianças pequenas, é necessário 0 comprometimento com a qualidade de seus professores, que se encontra, por sua vez, vinculada à sua formação profissional. Assim, poder-se-á contribuir também para a promoção de práticas educativas que permitam a essas crianças adquirir elementos que Ihes possibilitem participar ativamente da sociedade na qual estão inseridas, que é complexa, mas que pode e deve ser justa. Trata-se, não podemos nos esquecer, de um conjunto de medidas que precisa de uma atenção especial por parte do Estado brasileiro, especialmente no que se refere ao orçamento. Embora as perspectivas não sejam nada animadoras na atual conjuntura, em que os gastos públicos com serviços essenciais estão engessados pela trava do índice inflacionário, há de se pressionar as autoridades para que se conscientizem do dano que a falta de investimentos em uma área já tão historicamente desassistida, como a da Educação Infantil, poderá causar a médio e longo prazos. 


\section{CONSIDERAÇÕES FINAIS}

Discutir sobre temas que influenciam a prática docente na Educação Infantil, como os aqui propostos, parece fundamental para a promoção da qualidade nessa primeira etapa da Educação Básica. É certo que a posse de uma titulação que habilite o trabalho com crianças pequenas não garante que isso aconteça e que os professores venham a desenvolver um trabalho de qualidade junto a elas, já que inúmeros fatores de outra ordem também interferem, como as vicissitudes das políticas públicas destinadas à área. Isso significa dizer, entre outras coisas, que não se pode delegar total responsabilidade exclusivamente à formação, pois outros elementos (ideologia dominante, ausência de identidade profissional, condições de trabalho desfavoráveis, etc.) também interferem na elaboração/reelaboração das representações.

De acordo com Diógenes (1998), os cursos de formação devem proporcionar reflexões sobre os temas mais frequentes das representações, ou seja, sobre conteúdos que inquietam os professores e interferem em sua prática. Complementando esse pensamento, porém, acredita-se que alguns temas, como os aqui investigados, devem ser comuns na formação de todos os professores, já que provavelmente subsidiam a prática de todos eles. Assim, assuntos referentes ao gênero e às especificidades que envolvem essa profissão, por exemplo, devem ser alvo de debates constantes em todos os cursos de formação.

Por fim, e não menos importante, há de se ter um forte engajamento contra a forma perversa com que o Estado brasileiro trata o financiamento da educação, bem prejudicial, quando vista em conjunto, mas especialmente danosa à Educação Infantil. É necessária, pois, uma atitude política por parte dos que defendem a causa da educação em nosso país, pois são tempos em que o pensamento neoliberal viceja nos altos circuitos do poder, e, como sabemos, não vai ser pela via do sucateamento que conseguiremos dar o salto qualitativo que todos esperam no âmbito da educação pública no Brasil.

\section{REFERÊNCIAS}

ARCE, A. Documentação oficial e o mito da educadora nata na Educação Infantil. Cadernos de Pesquisa, São Paulo, n. 113, p. 167-184, 2001.

Educação \& Formação, Fortaleza, v. 4, n. 12, p. 82-103 set./out. 2019 
BAKHTIN, M. Marxismo e filosofia da linguagem: problemas fundamentais do método sociológico da linguagem. 14. ed. São Paulo: Hucitec, 2010.

BRASIL. Constituição de 1988. Constituição da República Federativa do Brasil. Diário Oficial [da] República Federativa do Brasil, Poder Executivo, Brasília, DF, 5 out. 1988.

BRASIL. Diretrizes Curriculares Nacionais para a Educação Infantil. Brasília, DF: MEC, 2010.

BRASIL. Emenda Constitucional n. 95, de 15 de dezembro de 2016. Altera o Ato das Disposições Constitucionais Transitórias, para instituir o Novo Regime Fiscal, e dá outras providências. Diário Oficial [da] República Federativa do Brasil, Poder Executivo, Brasília, DF, 16 dez. 2016.

BRASIL. Lei n. 9.394, de 20 de dezembro de 1996. Estabelece as Diretrizes e Bases da Educação Nacional. Diário Oficial [da] República Federativa do Brasil, Poder Executivo, Brasília, DF, 21 dez. 1996.

BRASIL. Subsídios para credenciamento e funcionamento de instituições de Educação Infantil. Brasília, DF: MEC, 1998.

CAMARA, L. B. A educação na Constituição Federal de 1988 como um direito social. Revista Direito em Debate, ljuí, v. 22, p. 4-26- 2013.

CAMPOS, M. M. Educar e cuidar: questões sobre o perfil do profissional de Educação Infantil. In: BRASIL. Por uma política de formação do profissional de Educação Infantil. Brasília, DF: MEC, 1994. p. 32-42.

CAMPOS, M. M. et al. Profissionais de creche. Cadernos Cedes, São Paulo, n. 9, p. 39-66, 1991.

CERISARA, A. B. A construção da identidade das profissionais de Educação Infantil: entre o feminino e o profissional. 1996. Tese (Doutorado em Educação) - Programa de Pós-Graduação em Educação, Universidade de São Paulo, São Paulo, 1996.

CERISARA, A. B. Professoras de Educação Infantil: entre o feminino e o profissional. São Paulo: Cortez, 2002.

CRUZ, S. H. V. Reflexões acerca da formação do educador infantil. Cadernos de Pesquisa, São Paulo, n. 97, p. 79-87, 1996.

DIÓGENES, A. L. N. Para além da palavra: um passeio pela infância no universo das ideias e das ações docentes na pré-escola. 1998. Dissertação (Mestrado em Educação) - Programa de Pós-Graduação em Educação, Faculdade de Educação, Universidade Federal do Ceará, Fortaleza, 1998.

EDWARDS, C. Parceiro, promotor do crescimento e guia: os papéis dos professores de Reggio em ação. In: EDWARDS, C.; GANDINI, L.; FORMAN, G. As cem linguagens da

Educação \& Formação, Fortaleza, v. 4, n. 12, p. 82-103 set./out. 2019

DOI: https://doi.org/10.25053/redufor.v4i12.1270

http://seer.uece.br/redufor 
criança: a abordagem de Reggio Emilia na educação da primeira infância. Porto Alegre: Artmed, 1999. p. 159-176.

GARDNER, H. Perspectivas complementares sobre Reggio Emilia. In: EDWARDS, C.; GANDINI, L.; FORMAN, G. As cem linguagens da criança: a abordagem de Reggio Emilia na educação da primeira infância. Porto Alegre: Artmed, 1999. p. IX-XII.

KRAMER, S. Profissionais de Educação Infantil: gestão e formação. São Paulo: Ática, 2005.

KUHLMANN JUNIOR, M. A Educação Infantil no século XIX. In: STEPHANOU, M.; BASTOS, M. H. C. (Org.). Histórias e memórias da educação no Brasil. Vol. II: século XIX. Petrópolis: Vozes, 2005. p. 68-77.

KUHLMANN JUNIOR, M. Infância e Educação Infantil: uma abordagem histórica. Porto Alegre: Mediação, 1998.

LASCARIDES, C.; BLYTHE, H. History of early childhood education. Abingdon: Routledge, 2000.

MACÊDO, L. C.; DIAS, A. A. A política de financiamento da educação no Brasil e a Educação Infantil. Revista Brasileira de Política e Administração da Educação, Porto Alegre, v. 27, p. 165-184, 2011.

MACHADO, M. L. A. Formação profissional para Educação Infantil: subsídios para idealização e implementação de projetos. 1998. Tese (Doutorado em Psicologia da Educação) - Programa de Pós-Graduação em Psicologia da Educação, Pontifícia Universidade Católica de São Paulo, São Paulo, 1998.

OLIVEIRA, E. Relações raciais nas creches diretas do município de São Paulo. 1994. Dissertação (Mestrado em Educação) - Programa de Pós-Graduação em Educação, Pontifícia Universidade Católica de São Paulo, São Paulo, 1994.

OLIVEIRA, Z. M. R. Diretrizes para a formação de professores de Educação Infantil. Revista Pátio Educação Infantil, Porto Alegre, v. 1, n. 2, p. 6-9, 2003.

OLIVEIRA, Z. M. R. (Org.). Educação Infantil: muitos olhares. 6. ed. São Paulo: Cortez, 2004.

OLIVEIRA-FORMOSINHO, J.; FORMOSINHO, J. (Org.). Associação Criança: um contexto de formação em contexto. Braga: Livraria do Minho, 2001.

PORTO, B. S.; CRUZ, S. H. V. Uma pirueta, duas piruetas... Bravo! Bravo! A importância do brinquedo na educação das crianças e de seus professores. In: CRUZ, S. H. V.; PETRALANDA, M. (Org.). Linguagem e educação da criança. Fortaleza: UFC, 2004. p. 213-231.

ROCHA, E. A. C. A pesquisa em Educação Infantil no Brasil: trajetória recente e perspectiva de consolidação de uma pedagogia. Florianópolis: UFSC/NUP, 1999.

Educação \& Formação, Fortaleza, v. 4, n. 12, p. 82-103 set./out. 2019

DOI: https://doi.org/10.25053/redufor.v4i12.1270

http://seer.uece.br/redufor 
ROSEMBERG, F. Organizações multilaterais, Estado e políticas de Educação Infantil. Cadernos de Pesquisa, São Paulo, n. 115, p. 25-63, 2002.

SCOTT, J. W. Gênero: uma categoria de análise histórica. Educação e Realidade, Porto Alegre, v. 16, n. 2, p. 5-22, 1990.

SILVA, A. P. S.; ROSSETTI-FERREIRA, M. C. Desafios atuais da Educação Infantil e da qualificação de seus profissionais: onde o discurso e a prática se encontram? In: REUNIÃO ANUAL DA ANPED, 23., 2000, Caxambu. Anais... Caxambu: Anped, 2000.

ZABALZA, M. A. Qualidade em Educação Infantil. Porto Alegre: Artmed, 1998.

\section{André Dioney Fonseca (Brasil, Pará, Santarém) \\ Universidade Federal do Oeste do Pará (Ufopa)}

Doutor em História Social pela Universidade de São Paulo (USP). Professor adjunto do curso de História da Ufopa. Docente do Programa de Pós-Graduação em Educação da Ufopa.

Lattes: <http://lattes.cnpq.br/5794497383094905>.

E-mail: <andredioney@yahoo.com.br>.

\section{Anselmo Alencar Colares (Brasil, Pará, Santarém)}

Universidade Federal do Oeste do Pará (Ufopa)

Doutor em Educação pela Universidade Federal de Campinas (Unicamp). Professor titular do curso de Pedagogia da Ufopa. Docente do Programa de Pós-Graduação em Educação da Ufopa.

Lattes: <http://lattes.cnpq.br/1107767923215438>.

E-mail: <anselmo.colares@gmail.com>.

\section{Sinara Almeida da Costa (Brasil, Pará, Santarém) \\ Universidade Federal do Oeste do Pará (Ufopa)}

Doutora em Educação pela Universidade Federal do Ceará (UFC). Professora adjunta do curso de Pedagogia da Ufopa. Docente do Programa de Pós-Graduação em Educação da Ufopa.

Lattes: <http://lattes.cnpq.br/4985156340614183>.

E-mail: <sinaraacs@hotmail.com>.

Recebido em 11 de maio de 2019.

Aceito em 03 de junho de 2019.

Educação \& Formação, Fortaleza, v. 4, n. 12, p. 82-103 set./out. 2019

DOI: https://doi.org/10.25053/redufor.v4i12.1270

http://seer.uece.br/redufor 